\title{
Zabezpieczanie księgozbiorów po II wojnie światowej w Polsce
}

Ryszard Nowicki 


\section{Ryszard Nowicki}

\section{Zabezpieczanie księgozbiorów po II wojnie światowej w Polsce}

W

latach 1945-1949 Polska dokonała olbrzymiego wysilku związanego z zabezpieczaniem księgozbiorów. Jeszcze w okresie walk z Niemcami na oswobodzonych terenach kraju przystąpiono do ochrony zbiorów. Sprawa była szczególnie istotna, zważywszy na fakt zniszczenia wielu milionów książek przez okupanta i ogromne potrzeby w zakresic odbudowy rodzimych bibliotek.

Szczególnie ucierpialy księgozbiory w stolicy po upadku Powstania Warszawskiego. W kraju najlepsze warunki do rozpoczęcia dzialań związanych z zabezpieczaniem istnialy w Krakowie. Miasto ocalało. Przetrwała Biblioteka Jagiellońska, pomimo wywiezienia części zasobu. Niewiele było tego rodzaju placówek w Polsce. 1)o tych, które zachowały większość swoich zbiorów, należały między innymi Książnica Kopernika w Toruniu, Biblioteka Miejska w Bydgoszczy, Biblioteka Kórnicka. Biblioteka Uniwersytecka w Poznaniu miała nawet powiększony zbiór w porównaniu ze stanem z 1939 rokı. Zachowały się również księgozbiory w Cieszynie.

O uratowanych książkach w miéście nad Olza donosil „Dziennik Zachodni” ur 111 z 24 kwietnia 1946 roku. W Muzeum Miejskim przetrwalo kilkadziesiąt tysięcy wolıminów. Pozostał znaczny fragment Biblioteki Józefa Ignacego Kraszewskiego, liczącej w 1939 roku blisko 18 tys. tomów. Straty wynosily okolo 10 procent. Podobne braki wykazywały Biblioteka Czytelni Ludowej (przed wojną okolo 13 tys. tomów), jak i Biblioteka Cieszyńskiego Towarzystwa Ludoznawczego (około 5 tys. tomów). Szczególnie cemmą Bibliotekę Leopolda Szersznika (do wybuchu wojny 12 tys. tomów) w dwóch trzecich wywieźli Niemcy na Zaolzie. W Muzeum przetrwał katalog'.

' Zbiory ewakuowane do Czechoslowacji powrócily do Cieszyna ua początku lat sześćdziesiątych. 
Po okupancie pozostala część biblioteki utworzonej przy Zentralinstitut fïr Oberschlesische Landesforschung. Byl to zbiór dużej wartości, z przewaga dziel rodzimych. Powstal głównie z książek skonfiskowanych z polskich bibliotek (między innymi Branickich-Tarnowskich z Suchej, Pszczólki z Katowic. Instytutu Śląskiego Towarzystwa Przyjaciól Nauk). Okofo 5 tys. tomów zabezpieczono w Muzeum cieszyńskim. W placówce umieszczono także i inne księgozbiory, które otoczono ochroną. W mieście zachowała się również biblioteka o znacznej wartości historycznej i nankowej - Tschammera, licząca około 10 tys. tomów. Kierownictwo Muzeum na łamach prasy apelowało do społeczności lokalnej o przekazanie ksiązek z bibliotek cieszyńskich, celem ochrony ich przed zniszczeniem.

Po II wojnie światowej zabezpieczeniu podlegaly księgozbiory stanowiące tak zwane mienie opuszczone ${ }^{2}$ i porzucone. Zgodnie z Ustawą z 6 maja 1945 roku o majątkach opuszczonych i porzuconych ${ }^{3}$, do pierwszej grupy zaliczano te, które w związku z wojną rozpoczęta 1 września 1939 roku nie znajdowały się w posiadaniu właścicicli (biblioteki poziemiańskie); w sklad drugiej wchodziły zbiory, które byly wlasnością lub w posiadaniu państwa niemieckiego, obywateli niemieckich bądź osób zbiegłych do nieprzyjaciela (biblioteki poniemieckie).

Akcję ochrony księgozbiorów zapoczątkowat okólnik z 29 listopada 1944 roku w sprawie zabezpieczenia bibliotek i zbiorów bibliotecznych Resortu Oświaty Polskiego Komitetu Wyzwolenia Narodowego. Obowiązek ten nalożono na inspektoraty i kuratoria szkolne. W Krakowie 15 lutego 1945 roku Minister Oświaty Stanisław Skrzeszewski wydal zarządzenie w sprawie zabezpieczania księgozbiorów na terenach wyzwalanych z niemieckiej okupacji. Ustanowil okręgowych kierowników bibliotecznych. którzy mieli przejmować i chronić zbiory.

Zostali nimi:

- dla województw krakowskiego i kieleckiego - dyrektor Biblioteki Jagiellońskiej w Krakowie;

- dla województwa śląskiego - dyrektor Biblioteki Publicznej w Katowicach;

- dla województwa łódzkiego - dyrektor Biblioteki Miejskiej w Łodzi;

- dla województw poznańskiego i pomorskiego — dyrektor Biblioteki Uniwersyteckiej w Poznaniu.

Ministerstwo Oświaty przystapiło w 1947 roku do realizacji drugiego etapu akcji gromadzenia i zuży tkowania zbiorów zabezpieczonych, który polegal na ich segregacji i repartycji. W związku z tym utworzono na początku tego roku zbionice-segregatornie w Gdańsku, Katowicach, Krakowie, Poznaniu, Szczecinie, Wroclawiu. Do ich zadań i kompetencji należało odszukanie i przewiezienie materiałów bibliotecznych, zmagazynowanie, segregacja oraz przekazywanie zbiorów na podstawie otrzymywanych upoważnień z Ministerstwa

\footnotetext{
¿Określenie .micnic opuszczonce" jest blędnc. W wyniku wprowadzanych zmian ustrojowych zicmianic często nic mogli wrócić do swoich dóbr.

3..Dzicmnik Urzędowy Ministerstwa Oświaty" nr 17 poz. 97.
} 
Oświaty. Zbiornice funkcjonowały do końca grudnia 1949 roku. Zaprzestanie dalszej pracy oznaczało zakończenie zabezpieczania księgozbiorów w Polsce.

Ministerstwo Oświaty nie było jedyną instytucją uczestniczącą w zabezpieczeniu zbiorów bibliotecznych. W tym zakresie działaly i inne, jak Ministerstwo Kultury i Sztuki, Ministerstwo Rolnictwa i Reform Rolnych, Ministerstwo Bezpieczeństwa Publicznego. Aktywność przejawiały w starostwach referaty kultury i sztuki; zarządy okręgowe Państwowych Nicruchomości Ziemskich; wladze lokalne, organizacje spoleczne i polityczne oraz inne czynniki.

Sprawa ochrony księgozbiorów należała do szczególnie pilnych. Zachowanym fragmentom groziło zniszczenie przez przechodzące wojsko, okoliczną ludność, wywóz do Związku Radzieckiego. Wiele z nich zostalo rozszabrowanych.

Zarząd Główny Bibliotek województw krakowskiego, kieleckiego i rzeszowskiego zachęcał Dyrekcję Związku Księgarzy i Wydawców w Krakowie do podjęcia stanowczych dzialań mających na celı ochronę książki. W Katowicach, Kielcach, Częstochowie i w Warszawie oferowano w sprzedaży znaczną ilość starych druków przywiezionych z Dolnego Sląska, co do których istniało uzasadnienie podejrzenie, że pochodzą z kradzieży.

Stale notowano przypadki wywożenia książek poniemieckich z Ziem Zachodnich i innych. Na skalę masową przewożono je w walizkach, plecakach, pakunkach. Korzystano nawet z pośrednictwa urzędów pocztowych. Niemalże wszystkie księgarnie oferowały cenne dziela pochodzące z terenów przylączonych do kraju w wyniku postanowień Wielkiej Trójki. Zachowania te szkodziły zabezpieczaniu księgozbiorów.

Ministerstwo Oświaty otrzymywało liczne sygnału z obszaru całego kraju o wywożeniu woluminów przez Armię Czerwoną ${ }^{+}$. Między innymi z Międzyrzecza zabrano duzą bibliotekę z dziełani w 38 językach; z powiatów Nidzica, Szczytno, Pisz wywieziono biblioteki podworskie; w Lęborku Rosjanic zajęli bibliotekę pedagogiczną. W wielı przypadkach nie można bylo stwierdzić ilości książek, gdyż żołnierze radzieccy nie pozwalali wejść na zajmowany teren.

W kraju nie było ustalonego wzoru postępowania związanego z ochroną księgozbiorów. Doświadczenie zdobywano w codziennej pracy, borykając się z licznynu problemami. Przy zabezpieczeniu korzystano ze Wskazóu'ek dla prouradzac)ch akcige zabezpieczenia bibliotek $i$ zbiorón bibliotecznych. Liczącą 16 stron publikację opracowaną przez Józcfa Grycza wydano z zasiłku Ministerstwa Oświaty Wydziału Bibliotek ${ }^{5}$.

Zabezpieczanie księgozbiorów w Gdańsku rozpocząl na początku kwietnia 1945 Marian Pelczar ${ }^{6}$, dyrektor Biblioteki Miejskicj. Akcję na terenie województwa gdańskiego pro-

\footnotetext{
${ }^{+}$Zob. Archiwum Akt Nowych w Warszawic (AAN), Ministerstu'o Ośriaty. Naczelma Dyrekcja Bibliotek. Re-

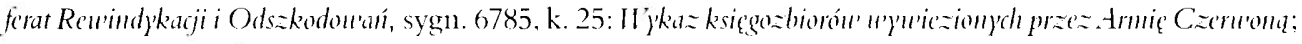

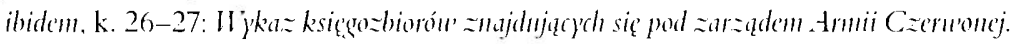

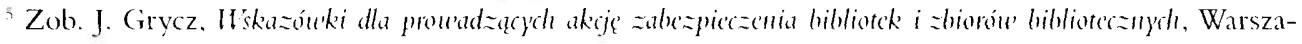
wa-Poznań 1945.

"Zob. M. Pclczar, Bibliotekı Micjskı u" Giduńsk" 1945-19.53, „Rocznik Gdański” t. 13, 1954. s. 159.
} 
wadziła, powstała dwa miesiące później przy Kuratorium Okręgu Szkolnego Gdańskiego, Komisja Wojewódzka Opieki nad Książkami.

Marian Pelczar zabiegał głównie o rewindykację zbiorów Biblioteki Miejskiej. Szereg dzieł odnaleziono w piwnicach Ratusza Starego Miasta w Gdańsku. W Pelplinie w zanurowanej części obiektów klasztornych odszukano ponad 20 tys. tomów. Najcenniejsze zbiory Niemcy wywieźli do Malborka. W zamku znajdowaly się obok innych ksiązek przywiezionych z Pomorza i Generalnej Guberni. Część uległa zniszczeniu podczas walk - skrzynie z książkami służyły jako zapory. Ogółem z Malborka odzyskano kilkadziesiąt tysięcy tomów. Były one transportowane bezpośrednio lub za pośrednictwem Ministerstwa Oświaty i Muzeum Wojska Polskiego w Warszawie.

W wyniku działań rewindykacyjnych Biblioteka odzyskała około 80 tys. pozycji. Z przeprowadzanej akcji zabezpieczającej księgozbiory porzucone i bezpańskie na terenie Gdańska i województwa gdańskiego zebrano około 300) tys. tomów. Tym zasobem dysponowala w latach 1947-1949 Zbiornica Księgozbiorów Poniemieckich w Gdańsku, która zaznaczyła swoją obecność także na terenie województwa szczecińskiego.

Księgozbiory poniemieckiej proweniencji z obszaru Pomorza Zachodniego zwoziły przede wszystkim różne placówki z kraju. Bibliotekę Miejską w Szczecinie objęły władze polskie dopiero w lipcu 1945 roku. Zabezpieczaniem księgozbiorów zajmowały się Zarząd Miejski w Szczecinie i Wojewódzka Komisja Opieki nad Książkami, powolana przez Kuratorium Okręgu Szkolnego Szczecińskiego.

Po drugiej wojnic światowej powstal Uniwersytet w Toruniu. Biblioteka Uniwersytecka, pod kierunkiem Stefana Burhardta, tworzyła swój księgozbiór głównie ze zbiorów zabezpieczonych na terenie Pomorza. Podstawą stały się księgozbiory poniemieckie. W Toruniu w zasadzie nie było żadnych dzieł do przejęcia ${ }^{8}$.

W roku akademickim 1945/1946 do miasta Kopernika zwieziono około 300 tys. tomów" Książki pochodzily głównie z następujących bibliotek ${ }^{11}$ : Miejskiej w Szczecinie, Miejskiej w Elblągu, uniwersyteckiej w Gryfii, Instytutu do Spraw Gospodarczych Rosji i Europy Wschodniej w Królewcu, Puttkamerów w Pęzinie, Pruskiego Banku Państwowego w Berlinie, gimnazjów w Sławnie, Słupsku, Wąbrzeźnie, Wystruciu: Bismarcka w Warcinie, Muzeum Miejskiego w Koszalinie, kościelnej w Jamnie, seminariów uniwersyteckich w Królewcu i innych.

Zob. ibidem, s. 163.

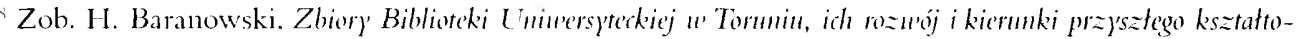

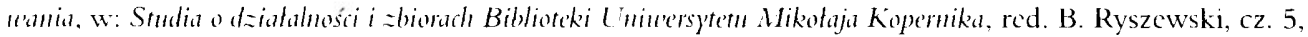
Toruní 199(). s. 24.

"Zob. Archiwum Uniwersytetu Mikolaja Kopernika w Tormniu. Biblioteka L MK. Spran'0zdania 1945/46-1946/47. sygn. 74, k. 4: Spranozdanic Biblioteki L'minersyteckiej " Tormin za rok akademicki 1945/46.

"Zob. ibidem. k. 5-6. 
Ogólem Biblioteka Uniwersytecka w Torminiu w latach 1945-1949 przetransportowała z Pomorza Wschodniego i Zachodniego oraz innych terenów około 600) tys. dzief ${ }^{\prime \prime}$. W początkowym okresie zbiór miała charakter wybitnie niemiecki. Podczas uroczystego otwarcia placówki, w maju 1947 roku, na półkaclı czytelni glównoj brakowalo polskich książek '². W liczącym ponad 30() tys. woluminów księgozbiorze stanowily one zaledwie 3 procent.

W Bydgoszczy pod koniec stycznia 1945 roku utworzono Komitet Ochrony Mienia Państwowego i Kulturalnego, kierowany przez Tadeusza Esmana. Zabezpieczaniem i zbiórką książek oraz pomocy naukowych zajmowat się Dział Biblioteczny ${ }^{13}$. Komitet w połowie kwietnia 1945 roku został przeksztalcony w Wojewódzkie Biuro do Spraw Archiwalnych i Bibliotecznych. Do początków września 1945 roku zgromadzono około 300 tys. tomów.

W mieście nad Brdą w lutym 1945 roku wznowil działalność Instytut Bałtyckit ${ }^{1+}$ Niezwłocznie przystąpil do odbudowy swoich zbiorów. Prace koordynowal powstaly w październiku tego roku Wydzial Biblioteczıy, kierowany przez I Ielenę I Iéb-Koszańską. Tematyka gromadzonych pozycji dotyczyła zagadnień morskich, pomorzoznawczych oraz regionu bałtyckiego. Instytut uczestniczył w zabezpieczeniu księgozbiorów. Z przydziału wladz centralnych przywieziono między innymi 6955 woluminów przekazanych w charakterze depozytu z Biblioteki Miejskicj w Elblągu oraz na takich samych prawach około 2 tys. wolıminów z księgozbioru Towarzystwa Pomorzoznawczego w Szczecinie.

Dolny Śląsk został objęty częściowo akcja zabezpieczania księgozbiorów prowadzoną przez dyrektora Biblioteki Uniwersyteckiej w Poznaniu Aleksandra Birkenmajera. Ministerstwo Oświaty upoważnilo profesora do zabezpieczenia i przetransportowania księgozbiorów i archiwaliów poniemieckich, znajdujących się w pałacach w Miliczu i Sławie ${ }^{15}$.

Najcenniejszym księgozbiorem zabezpieczonym przez profesora była biblioteka w Stawie, mieszcząca się w zamku stanowiącym dawną rezydencję I Iimmlera. Zawierala szczególnie cenne masonica.

Ze Slawy do Poznania skierowano od czerwea 1945 do 11 maja 1946 roku ponad 20 transportów. Przewożenie około 150 tys. tomów zajęło prawie rok. Dłıgi okres był związany z trudnościami w zdobyciu środków przewozı oraz brakiem wystarczających

${ }^{11}$ Zob. H. Baranowski, Zbiory.... op. cit., s. 26.

12 Zob. M. Puciatowa, Biblioteka Glónta, w: Limerestet Mikotaja Kopernika 1945-1955, red. R. Galon, Warszawa 1957. s. 313.

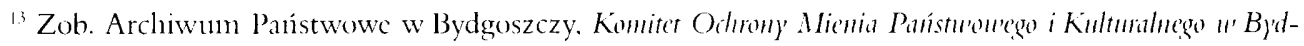
goszezy. Zabezpiezamie mienia panstu'on'ego i kulturalnego 1945, sygn. 3. bez pagin.: Konnitet Oderony' Mienia Pansturourego i Kulturalnego Dziut Bibliotecent. Sprandozdanic [11/III 1945].

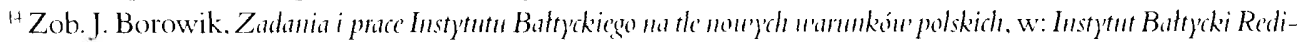

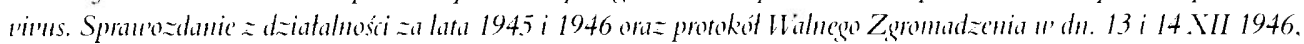
"Paniçtnik Instytutu Baltyckicgo", red. I. Borowik, 11r 43. Gdańsk-Bydgoszcz-Szczecin 1947, s. 12.

is Zob. Archiwum Bibliotcki Uniwersytetu Adama Mickiewicza w Poznaniu, Referat zabezplezania i se-

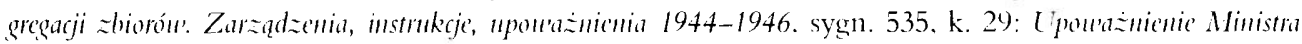

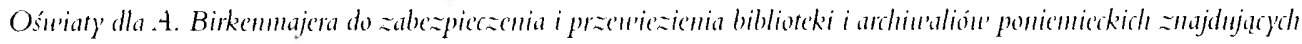

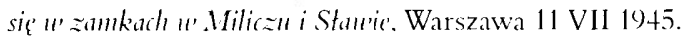


środków finansowych. Przyczyniły się do tego również dlugotrwałe przerwy wywołane nieporozumieniem na tle prawomocności poznańskiej Biblioteki Uniwersyteckiej w stosunku do biblioteki znajdıjącej się na terenie Dolnego Śląska. Na tym obszarze wykazywaly aktywność i inne ośrodki, jak Kraków (Biblioteka Jagiellońska) czy Warszawa ${ }^{16}$.

Największe skupiska księgozbiorów na terenie Sląska znajdowały się we Wrocławiu. Do najważniejszych należaly zbiory Biblioteki Uniwersyteckiej, Biblioteki Miejskiej i Biblioteki Kapitulnej. W czasie II wojny światowej były one częściowo ewakuowane i rozlokowane w terenie. Okupant uważał obszar Dolnego Śląska za bardzo bezpieczny. Celem ochrony przed nalotami zwoził tutaj liczne księgozbiory niemieckie oraz zagrabione z ziem polskich i imnych państw europejskich.

Wroclaw 19 styczuia 1945 roku zostal ogłoszony twierdzą. Zacięte walki o zdobycie miasta trwały do 7 maja. W okresie krwawych zmagań, w kwietniu 1945 roku, powstała w Krakowie pionierska grupa Uniwersytetu Wrocławskiego, w skład której weszło około 30 osób. Minister Oświaty 20 kwietnia 1945 roku mianował Stanisława Kulczyńskiego delegatem Rządu Rzeczypospolitej do zabezpieczenia majątku i urządzeń wyższych uczelni, instytucji naukowych, bibliotek oraz zbiorów na terenie Wrockawia i okolic ${ }^{17}$. Grupa naukowo-kulturalna, pod kierunkiem rektora Stanisława Kulczyńskiego, przybyła do miasta 10 maja 1945 roku.

Dzień wcześniej, 9 maja, do Wrocławia dotarła trzyosobowa czolówka pionierów, w skład której wchodzili: Antoni Knot, Włodzimierz Kozak i Stanisław Kamiński ${ }^{1 ષ}$. Ekspedycja zwiadowcza, mająca na celı zabezpieczenie zachowanych w mieście i okolicy bibliotek ${ }^{1 "}$, była świadkiem tragedii, związanej ze spaleniem 11 maja części zbiorów Biblioteki Uniwersyteckiej. Okupant 18 marca 1945 roku postanowił wysadzić budynek Biblioteki na Wyspie Piaskowej, by w ten sposób zamaskować gruzami niemiecką kwaterę dowództwa. Około 200 osób przenosiło książki do sąsiedniego kościoła św. Anny ${ }^{20}$. Transportowanie zbiorów zakończono 4 maja. Kilka dni później wybuchł pożar, który zniszczył około 300 tys. tomów ${ }^{21}$.

"Zob. M. Dąbrowski. Ksaneergo Śruicrkou'skicgo uralka o dobra kultury', „Roczniki Bibliotecznc” R. 24: 1980 z. 1. s. $111-125$.

${ }^{17}$ Zob. W. Wrzesinski. Liniurerstet Wroctan'ski 1945-1995, Wroclaw 1995, s. 16.

"Zob. S. Nawara. Zarys dziejón Biblioteki liniucrspteckicj we Wroctawin 1945-1955, Wrochaw 1955, s. XIV;

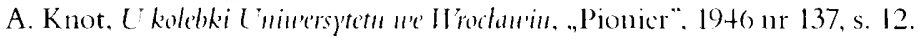

"Zob. Archiwum Bibliotcki Jagiellońskicj. Spran'ozdumia Biblioteki Jagielloniskiej, Sprau'ozdania Dyrekcji Biblioteki Jagielloniskiej od 18 I do 31 I'llI 1945 oraz za lata akademickie 1945/46-1949/50, bez pagin. - Spraurozdanic Dyrekciji Biblioteki Jagielloniskicj an a as od 18 stycania do 31 sierpmia $1945 \mathrm{r}$.

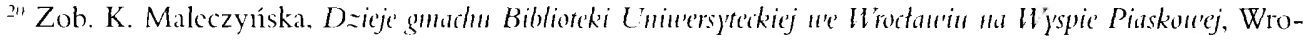
claw-Warszawa 1960), s. 15.

${ }^{2}$ Zob. ihidem. s. 16: O. Kape, Die Geschichte der wissenschaftlichen Bibliotheken in Breskan in der Zeit ron 1945 bis 1955: unter besonderer Berieksidtigning der Liniersitütshihliothek, St. Katharinen 1993, s. 31 i nast. 
Pełnomocnik Ministerstwa Oświaty Stanislaw Kulczyński 10 maja 1945 roku powierzyl Antoniemu Knotowi ogólne kierownictwo bibliotek na terenic Wroclawia oraz polecil zabezpieczyć wszelkie księgozbiory poniemieckie, księgarnie, antykwariaty ${ }^{22}$. Rozpoczął on niezwlocznie akcję oraz organizowanie od podstaw polskiej Biblioteki Uniwersyteckiej, w której objąl stanowisko kierownika, a następnie dyrektora ${ }^{23}$. Jako kierownik Referatu Rewindykacyjnego Uniwersytetu i Politechniki przeprowadzal rewindykację zbiorów w latach 1945-1946 na terenic Wrocławia i Dolnego Śląska.

Szereg wiadomości o księgozbiorach przekazywały osoby niezwiązane z akcją zabezpieczenia. Według uzyskanych między imnymi tą drogą informacji Antoni Knot zlokalizował na terenie Dolnego Śląska i Opolszczyzny 70 schowków. Znajdowaty się one w zankach, palacach, pomieszczeniach gospodarczych, a nawet celach więziennych ${ }^{2+}$. Po przybyciu na miejsce okazało się, że część z nich była pusta lub zawierała dzieła zdewastowane ${ }^{25}$.

Naplywające wiadomości skrzętnie notowano. Szereg z nich zostało zapisanych w $N_{0-}$

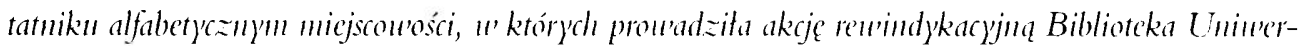
sjtecka u' latad 1945-1946-26. Dokument ten zawicra szczególnie cenne informacje odnoszące się do księgozbiorów z terenu Dolnego Sląska. Dotyczą one między innymi krótkiej charakterystyki zbiorów, orientacyjnej ilości (przeliczanej na kilogramy, wagony, tomy), proweniencji, stanu zachowania, miejsca przechowywania, odległości do danej miejscowości, stosunku okolicznej ludności oraz wojsk radzieckich do zbiorów. Przykładowo w Grodzisku niedaleko Zlotoryi, na przelonie lutego i marca 1945 roku, splonęło w zanku okoto 250) skrzyń Preussische Staatsbibliothek w Berlinie. Rosjanie wywieźli z tej miejscowości bibliotekę Ost-Europainstitut, przywiezioną przez Niemców z Wrocławia. Na miejscu pozostały katalogi alfabetyczny i systematyczny ${ }^{27}$. W Miliczu przetrwała biblioteka hr. Malzanów, licząca około 24 tys. tomów ${ }^{28}$. Do I lenrykowa zwieziono inkunabuly z Biblioteki Diecezjalnej we Wrocławiu. W Mileszycach około 100 skrzyı́ bliżej nieokreślonego księgozbioru „Iudzie rozwlekają po okolicy”-29. Bibliotekę w oleśnickim zamku spalili Rosjanie. Część zbiorów przetrwala w kościcle. By tam dotrzeć, należato uzyskać pozwolenie sowieckiego komendanta Wrocławia, któremu podlegala Oléśnica ${ }^{301}$. W Notatniku podano

22 Zob. Archiwum Uniwersytetu Wroclawskiego (A UWr), Knot Antoni 1945-1974. sygn. RK-120, k. 31:

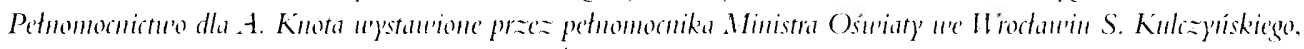
[Wroclaw] 10 V 1945; ibdem, k. 25: A. Knot. Zjeierys, Wrodaw 29 I 1955.

23 Zob. ibidem. k. 33: Rektor S. Kulizyriski do Ministerstu'a Ośurat). [Wrocławl 23 XI $19+5$.

2t Zob. S. Nawara. Zarys.... op. cit., s. XIX.

${ }^{25}$ Zob. J. Ożóg. Zurys historii Biblioteki Lminersyteckicj we Hroctumin. Wroclaw 1995, s. 80.

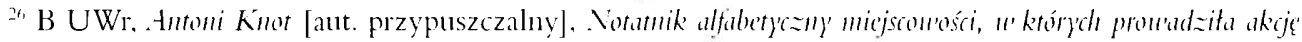

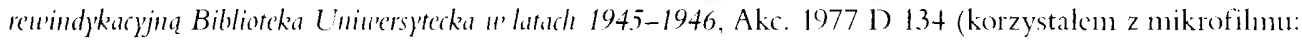
Mf 4 () 332).

${ }^{77}$ Zob. ibidem. k. 91: Grodzisko.

2* Zob. ibidem, k. 176-177: Milica.

"Zob. ibidem, k. 178: Milesz ya'.

3") Zob. ibidem, k. 2(19)-210: Oleśnica. 
szereg lakonicznych wiadomości i o innych miejscowościach, na przykład Adelinie, Bolkowie, Bystrzycy Kłodzkiej, Jcleniej Górze, Klodzku, Lwówku Śląskim, Obornikach Śląskich, Strzegomiu, Szklarskiej Porębie Trzebnicy, Wałbrzychu, Wrocławiu, Żmigrodzie.

W tym czasie zatrudnionych bylo ponad 60 pracowników niemieckich, $z$ tego $14 \mathrm{w}$ sortowni. Największa z nich grupa, licząca 27 lıdzi, pracowała fizycznie, natomiast 10 wykonywało czynności umyslowe. Niektórzy działali bardzo of iarnie. Na przykład przy pracach porządkowych we wroclawskiej Bibliotece Uniwersyteckiej dużą pomoc oddał Willi Polte ${ }^{31}$.

Rozpoczęty 9 maja 1945 roku pierwszy okres zabezpieczenia zbiorów trwal do 8 czerwca 1946 roku. Zakoníczony został podczas Dni Kultury Polskiej we Wroclawiu, obchodzonych 8-10 czerwca. Nastapilo wtedy uroczyste przekazanie Uniwersytetowi przez Radę Miejską budynku przy ul. K. Szajnochy 7/9 oraz zbiorów dawnej Biblioteki Miejskiej. W tym pionierskim okresie Antoni Knot prowadzil doraźne działania o charakterze zabezpieczeniowo-rewindykacyjnym na obszarze miasta oraz Dolnego Śląska. Uratował przed zniszczeniem liczne księgozbiory, w tym fragmenty Biblioteki Uniwersyteckiej i Biblioteki Miejskiej. W wyniku jego zabiegów zwieziono ponad 100 ciężarowych aut cennych książek naukowych i zbiorów. We Wroclawiu, z mienia poniemieckiego, zabezpieczono około $1 \mathrm{mln} 200$ tys. tomów. Z terenu Dolnego Śląska zwożono książki ukryte przez Niemców w schowkach. Ocalono około $16(0)$ ton książek i liczne wagony archiwaliów ${ }^{32}$.

W 1946 roku zakończył się okres największego nasilenia akcji zabezpieczeniowej i rewindykacyjnej ${ }^{33}$. Działania kontynuowano w następnych latach, ale już na mmiejszą skalę. Okres drugi, trwający od czerwca 1946 do 1949 roku, polegał głównie na czynnościach porządkowych i organizacji wewnętrznej pracy Biblioteki.

Ogółem uratowano w mieście i na obszarze Dolnego Śląska około $3 \mathrm{mln}$ woluminów ${ }^{34}$. Znajdowaly się wśród nich fragmenty Biblioteki Uniwersyteckiej, Biblioteki Miejskiej, bibliotek kościelnych oraz inne. Do Biblioteki Uniwersyteckiej trafilo 211917 woluminów z dawnych zasobów i ponad $1 \mathrm{mln}$ woluminów z innych zbiorów zabezpieczonych (na przykład część biblioteki Milicha ze Zgorzelca oraz Hochbergów z Książa, księgozbiór Gómołużyckiego Towarzystwa Naukowego ze Zgorzelca, księcia Jerzego Rudolfa z Legnicy, cenne zbiory szkolne ${ }^{35}$ ).

Zabezpieczone i zwiezione przez Antoniego Knota dzieła miały charakter poniemiecki. We Wroclawiu, podobnie jak w Toruniu, wystąpil problem polonizacji zbiorów. W wyniku zabiegów dyrektora Ministerstwo Oświaty przekazalo do Wrocławia część druków pol-

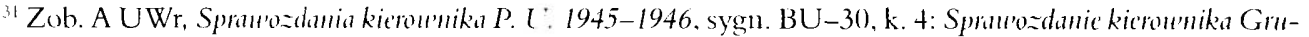

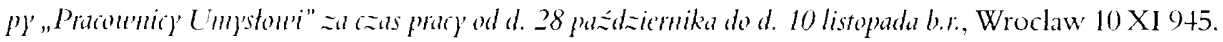

${ }^{32}$ Zob. S. Nawara. Zary's... op. cit., s. XXVIII.

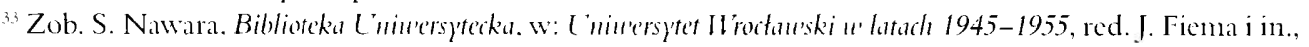
t. 1. Wroclaw 1959. s. 321.

${ }^{3+}$ Zob. J. Ożóg. Zarys.... op. cit.. s. 80.

${ }^{35}$ Zob. ibide'm.
} 
skich z bibliotek podworskich zabezpieczonych na terenie Małopolski. Do miasta nad Odrą trafily przekazane przez wladze radzieckie zbiory lwowskiej Biblioteki Ossolińskich. Antoni Knot zorganizowal we Wrockawiu Zakład Narodowy im. Ossolińskich ${ }^{36}$, którego byl dyrektorem w latach 1946-1949.

O licznych problemach związanych z zabezpieczaniem zbiorów świadczą między innymi losy biblioteki Schaffgotschów. Wiosną 1946 roku przybył do Cieplic delegat Wydziału Bibliotek Ministerstwa Oświaty Stanislaw Sierotwiński celem wywiezienia z terenu Dolnego Śląska tego księgozbioru. Przeciwko takiej możliwości zaprotestowała Rada Naukowa Instytutu Sląskiego w Katowicach na konferencji odbytej 6 kwietnia 1946 roku we Wroclawiu $^{37}$. W piśmie skierowanym do Ministerstwa Oświaty wskazywano na szczególne znaczenie, jakie posiada jedna z najwiçk szych bibliotck prywatnych dla całego Śląska. Zbiór liczyl około 8() tys. tomów. Biblioteka była uporządkowana. Przypuszczano, że posiada największy w kraju zbiór silesiaców. Zawierała między innymi druki nieznane Estreicherowi, niewyzyskane pod względem naukowym, szereg dokumentów dotyczących przeszłości Śląska pod względem kulturalnym i narodowościowym.

Biblioteka ta w ten sposób kompletowana ma przede wszystkim wartość dla Śląska i ze względı na swoją treść powinna zostać tam, gdzie dotychczas byla przechowywana (...). Instytut Śląski w Katowicach wraz ze swym Oddziatem we Wroclawiu nastawiony specjalnie na badanie stosunków kulturalnych, spolecznych i ekonomicznych Śląska, może oprzeć swą dzialalność naukową jedynie pod warunkiem, że skarby biblioteki Schaffgotschów zostaną mu udostępnione. W tych warunkach wywiezienie tej biblioteki z Cieplic byłoby prawdziwą klęską dla świata naukowego na całym Śląsku -

$\operatorname{argumentowano}^{38}$. Wskazywano, ze Uniwersytet Wrocławski w wyniku spalenia wlasnej Biblioteki może prowadzić badania naukowe z dziedziny nauk polonistycznych, historycznych i spolecznych jedynie w oparciu o tę bibliotekę.

Za pozostawieniem jej na miejscu, według uczestników konferencji, przemawiały również względy polityczne:

Ruszenie jej z dotychczasowego miejsca oznaczałoby w oczach nieprzychylnie dla nas nastawionej i śledzącej każde nasze przedsięwzięcie ludności niemieckiej po prostu, że Polska rezygnuje z Dolnego Śląska, że czuje się tu niepewnie, dając tym samym broń do ręki tym, którzy nie wierzą w utrzymanic

\footnotetext{
3. Zob. A UWr. Kinot Antoni 1945-1974, sygn. RK-120, k. 25: A. Knot. Źyciory's, Wroclaw 29 I 1955.

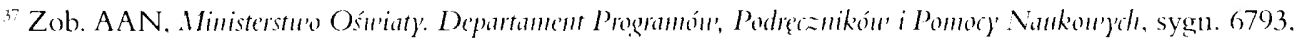

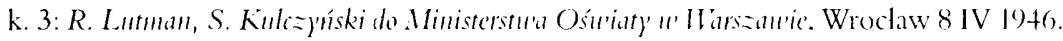

is Ibidem.
} 
przez Polskę przyznanych jej konferencją poczdamską terytoriów. Skutek takiego pociągnięcia może być i 11 a forum międzynarodowym fatalny ${ }^{39}$.

Postulowano przekazanic jej do użytku Uniwersytetowi Wroclawskiemu oraz Instytutowi Śląskiemu.

Sprawa księgozbioru Schaffgotschów była wielokrotnie dyskıtowana. Wrócono do niej między innymi podczas posiedzenia Komisji do Spraw Zbiorów Kulturalno-Naukowych Dolnego Śląska, odbytego 8 czerwca 1947 roku w Cieplicach-Zdroju ${ }^{+1}$. Przy okazji poruszono problem braku współdziałania i jednolitej polityki kulturalnej. Przestrzegano przed robieniem pustki kulturalnej na obszarze Dolnego Śląska. Opowiadano się za pozostawieniem zbiorów na miejscu ${ }^{+1}$. Wskazywano na zjawiska negatywne - przy okazji zbiórki papieru na makulaturę przemielono bezcenne plany regulacji Odry i budowy portów nadodrzańskich ${ }^{42}$.

Ostatecznie w Cieplicach 24 stycznia 1949 roku podpisano Protokót przekazania i praejecia depozytu Biblioteki dau'ncj Schaffgotschów ${ }^{+3}$. Za podstawę przekazania został wzięty stan podany w protokole przejęcia biblioteki Schaffgotschów przez Zbionicę Księgozbiorów Zabezpieczonych we Wrocławiu 2 października 1948 roku. Część książek trafiła do Biblioteki Narodowej, a część do Wroclawia (silesiaca).

W ochronic zbiorów uczestniczyła również Śląska Biblioteka Publiczna w Katowicach. Od lutego do sierpnia 1946 roku zabezpieczyla około 18 tys. tomów poniemieckich dzieł naukowych ${ }^{++}$. Największą partię zbiorów zwartych zabezpieczonych przez tę placówkę stanowiła Biblioteka Górnośląska (Oberschlesische Landesbibliothek) w Bytomiu (67 tys. tomów bez dubletów).

Próbę koordynacji działań, związanych z zabezpieczeniem księgozbiorów, z ramienia Ministerstwa Oświaty podjąt Stanisław Sierotwiński. Pełnił on od 1 grudnia 1945 do 30 kwietnia 1947 roku urząd delegata Ministerstwa Oświaty do zabezpieczenia księgozbio-

\footnotetext{
${ }^{34}$ Ibidcm.

4" Zob. A UWr. Protokoty przejgcia-przekazania =bioróm 1947. sygn. BU-84, k. 61-67: Protokót z posicdzenia

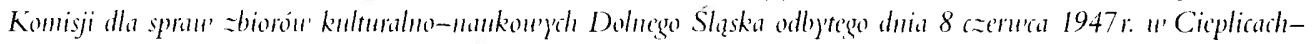

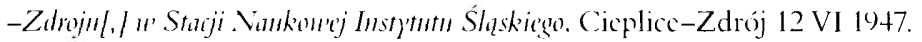

${ }^{+1}$ Zob. ibidem. k. 65-60.

22 Zob. ibiderm, k. 64.

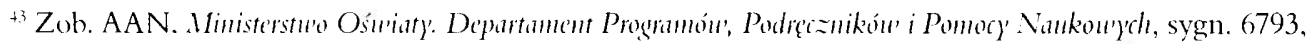

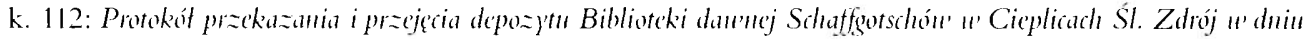

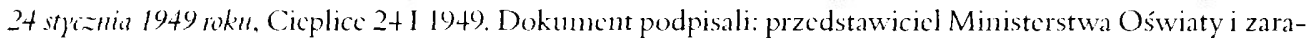
zen kicrownik Zbionnicy Ksiçgozbiorów Zabezpicczonych we Wroclawiu dr Edward Zubik, kierownik bibliotcki in. J. S. Bandtkiego w Cicplicach Jadwiga Bilgorajska, przedstawiciel Ossolincum mjr Juliusz Zulawski, zastẹpea dyrektora Biblioteki Narodowej Ksawery Swicrkowski. kustosz Biblioteki narodowej Bogdan Horodyski.

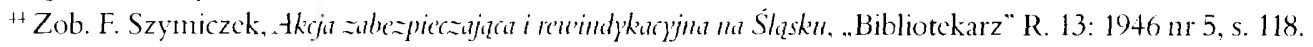


rów opuszczonych i porzuconych z siedzibą w Krakowie. Podlegal mu obszar podzielony na sześć okręgów:

I. Krakowski (wraz z (Bliwicami, Bytomiem i Raciborzem);

II. Wrocławski (obejmowal przyłączony Śląsk, bez punktów włączonych do Okręgu Krakowskiego);

III. Szczeciński (rozciągał się na obszar zachodniopomorski);

IV. Gdański (województwo gdańskie);

V. Olsztyı́ski (zajmowal resztę przyłączonych ziem);

VI.Lubuski (Ziemia Lubuska wraz z powiatami przyłączonymi do woj. poznańskiego).

Od 1 grudnia 1945 do 31 grudnia 1946 roku odszukal i zabezpieczyl okoto 5 mln 500 tys. książek, z tego około $1 \mathrm{mln} 800$ tys. przetransportowal do Krakowa. Szczególnic intensywną akcję prowadził na Dolnym Śląsku, gdzic uratował ponad 2 mlı dzieł. Z tego terenu zwiózl do Krakowa okoto $1 \mathrm{mln} 700$ tys. tomów (w ponad 90 procentach pochodzenia poniemieckiego). Zabezpieczył w Krzeszowie pod Kamienną Górą, przewiezioną w czasie wojny przez Niemców, część najcenniejszych zbiorów berlińskiej Prenssischer Stantsbibliothek — „Berlinkę”, którą w latach 1946-1947 ulokowano, zachowując ścisłą tajemnicę, w Bibliotece Jagiellońskiej. „Berlinka” obejmuje kilkaset tysięcy pozycji, bezcennych zabytków kultury niemieckiej. Wśród nich znajdują siç unikatowe rękopisy, inkunabuly, starodruki, zbiory graficzne i kartograficzne. Do szczególnie wartościowych należą muzykalia, obejmujące między imnymi utwory L. van Beethovena, J. S. Bacha, W. A. Mozarta, F. Mendelssohna-Bartholdy'ego, R. Schumanna, F. Schuberta.

W Polsce, w latach 1945-1949, różne ośrodki i instytucje uczestniczyły w zabezpieczaniu księgozbiorów. Pracowano w trudnych powojennych warunkach. Brakowalo środków finansowych, transportn, wykwalifikowanych pracowników, magazynów do składowania zwiezionych dzieł. W wyniku ofiarnej pracy Stanistawa Sierotwińskiego, Aleksandra Birkennajera, Antoniego Knota, Mariana Pelczara, Stefana Burhardta i innych ocalono miliony tomów przed zniszczeniem i rozgrabieniem. 